\title{
PHILOSOPHY
}

\section{ERICH FROMM'S "HUMANISTIC RADICALISM". HISTORICAL OCCURRENCE AND POLITICAL ACTIVITY}

\author{
Master of Religious Studies, Habriielian A. \\ Ukraine, Kyiv, Dragomanov National Pedagogical University \\ Applicant of the Department of Theology and Religious Studies
}

DOI: https://doi.org/10.31435/rsglobal_sr/31072019/6613

\section{ARTICLE INFO}

Received 25 May 2019

Accepted 15 July 2019

Published 31 July 2019

\section{KEYWORDS}

human, civilization, activity, Erich Fromm, humanistic radicalism, social psychoanalysis, healthy society, consciousness, social character

\begin{abstract}
The purpose of this article was to study the creative heritage of Erich Fromm and the formation of «Humanistic Radicalism». The study was aimed at defining the historical context for the theoretical formation of «Humanistic Radicalism» within the framework of Fromm's «Social Psychoanalysis» and the practical implementation of this concept in the political activities of this personality. Four periods of the introduction of the ideas of «Humanistic Radicalism» by E. Fromm through his political activities were identified. It was found out that the humanistic orientation requires the continuation both in research activities of a person and in everyday socio-cultural life in general, while maintaining dialogical relations with the world.
\end{abstract}

Citation: Habriielian A. (2019) Erich Fromm's "Humanistic Radicalism". Historical Occurrence and Political Activity. Science Review. 6(23). doi: 10.31435/rsglobal_sr/31072019/6613

Copyright: (C) 2019 Habriielian A. This is an open-access article distributed under the terms of the Creative Commons Attribution License (CC BY). The use, distribution or reproduction in other forums is permitted, provided the original author(s) or licensor are credited and that the original publication in this journal is cited, in accordance with accepted academic practice. No use, distribution or reproduction is permitted which does not comply with these terms.

Introduction. Increasingly, scientists point to the deadlock situation of human civilization, they say that «man and history have come to an end» [3]. In this regard, the appeal to the creative heritage of thinkers, rethinking the usual ways of dealing with reality, deserves special attention. Among them is Erich Fromm, well known to the scientific community and whose ideas served as a catalyst for philosophical disputes and discussions that raised a very large stratum of socioanthropological and ethical issues. Over the years, interest in the achievements of Fromm has increased immeasurably, because in his system of «humanistic radicalism» he largely anticipated the formulation and partial solution of the actual problems of our time.

Research results. Erich Fromm is the founder of many research programs studying global problems in the complex, interdisciplinary cognition of man. His warning is a tragic statement: «A man has such means of destruction, before which love of life may be powerless» [5, p. 51].

In the last two or three decades, almost all of the fundamental works of Erich Fromm, each of which contains a world-view core aimed at tomorrow, revealing «new compounds the molecule of the Human race» (E. Fromm) as a whole, have been published. «I believe», writes E. Fromm, «that every human being represents all humanity. We differ in reason, health, and ability. However, we are all alone. We all are saints and sinners, adults and children, but none of them exceeds the other and does not judge him. All of us were inscrutable with the Buddha, crucified us all together with Christ, but we killed and robbed us all along with Genghis Khan, Stalin, and Hitler» [5, p. 37]. Describing the «human situation», E. Fromm, who knows the secrets of social change and the psychological device of man, designs this situation in the coming times and prescribes the so-called today's day in a new cycle 
of human existence. Through the heart of E. Fromm, let's allow for a comparison, the fracture that split exactly in the historical moment of the XX century reality makes itself known in the XXI century.

Increasing the dehumanization of a person raises the question of the ecology of his consciousness «at the forefront». In other words, human problems, being one of the main problems for many millennia of human history, appeared in the XXI century as a complex scientific problem, which requires not only the theoretical reflection but also practical solution.

The line of Erich Fromm is «humanistic radicalism» as the «alpha» and «omega» of being. With the implementation of the principle of «humanistic radicalism,» as well as the search for ways of actualizing human in a person in the process of its life-creation, with the identification of mechanisms for updating the creative potential of the individual, we associate the possibility of adequate selfdetermination of man in the world and the emergence of a crisis state, which was a modern civilization. By E. Fromm, the concept of «humanistic radicalism» has the most powerful heuristic potential, first of all, in the study of the problem of society and its power structures.

According to E. Fromm, the violence that gives rise to fear is the factor that pushes a person to accept fiction and illusions for the truth. It is the atmosphere of violence that deforms the mind and the person's feelings. "There is an acute political need for such people who, being experts in their business and interested in politics, could freely express what they know and think», said once in an interview with Schulz Erich Fromm - personality in full political, but with the characteristic feature of independence and freedom [5, p. 52].

The increased interest of E. Fromm in public and political issues, which became a prerequisite for the creation of an image of a new society, has appeared since the early '50s. Certain role in this, undoubtedly, has played Fromm's life in Mexico, where he moved in 1949 and began to work on the creation of a psychoanalytic institute. All his time studies the phenomenon of capitalism in the past and the New Age, as well as the study of the history of socialist social projects. In 1955, E. Fromm publishes the book «Healthy Society», which creates the image of an inalienable society with a healthy physical structure. Fundamentally new is the emphasis of Fromm on the socio-psychological approach to the «Social Character», which is a kind of key to a «Healthy Society». In 1960, he joined the Socialist Party of the United States, forming a new program focused on the humanism of Marx, which was rejected due to the resistance of the party bureaucracy. «With all my optimism, I could no longer remain in the ranks of the American Socialist Party», remembers E. Fromm [5, p. 59]. He leaves the party and looks for other forms of political activity [6, p. 110].

The first form of the political activity of Fromm: the compilation and distribution of texts with a statement of the position on topical political issues. In particular, the «Bulletin of the correspondent committee» published open letters discussing foreign policy issues related to the Soviet Union, China, the Cuban crisis, and the development of Israel in support of the movement to protect peace on Earth.

The second form of political activity is the organization and participation of political movements. For example, in the period from 1957-1968, E. Fromm gave much time, forces and inspiration, money to protect the world, demonstrating the initiative of disarmament. In 1957, he participated in the founding of the «National Center for Health Policy».

Speaking against nuclear weapons, against hostilities, Erich Fromm set out his vision of a «healthy society»: «Our security is laid out smartly and healthily of thinking. This implies realism oriented towards the mind, which knows the facts about the enemy and of himself, judging by the probability not only based on possibilities, but also on the re-examination of the facts, but not admired by future projects, servants of self-justification» [6, p.127]. Speaking for a consistent policy of disarmament, he wrote: «It's about people! The present situation of mankind is extremely serious. The policy of elimination will never bring peace, it is very possible that it will destroy civilization and will undoubtedly destroy democracy even if peace was saved. The first steps to address the danger of an atomic catastrophe and the preservation of democracy are to unite for global disarmament» [6, p.127].

The third form of E. Fromm's political activity: articles and books, on the one hand, have an educational character; on the other - it contains an analysis of the actual political situation. In the work «The Concept of Man in K. Marx» (1961), Fromm researches the thinking of K. Marx and publishes the most important parts of the «Economic Philosophical Manuscripts of 1844» and «German Ideology» (1845-1846). Having made a huge impression on his publication on American neo-Marxists, he became the largest figure for them (Note: In America, during the Cold War and anti-communism, there was no English translation of Marx's early works, only in 1959, a translation appeared in England, made in the Soviet Union by T.B. Bottomor (born 1920), an English sociologist of the neo-Marxist orientation, with whom E. Fromm was in great friendship). Fromm, anxious for the fate of mankind, tried to expose certain 
or other fictions of American and Soviet foreign policy, using the means of the psychoanalyst in the analysis of the historical process. «The Soviet Union» writes E. Fromm «is a conservative totalitarian state of managers, not a revolutionary system that seeks world domination» [6, pp.127-128].

The fourth form of political activity E. Fromm: collective or personal appeals to politicians and statesmen, signatures under relevant resolutions, participation in political movements. In 1965, Fromm organized an exchange of views among socialist-humanists from different countries in the form of a collection of articles entitled «Symposium on Socialist Humanism». Ernst Bloch, Bertrand Russell, Leopold Senghor, Herbert Marcuse, Daniel Dolce, T.B. Bottomor, Irving Fetcher, as well as socialists Mikhail Markovich, Gayo Petrovich, Predrag Vranitsky and Adam Schaff in their articles showed that, in addition to the capitalist model of socialism, there is also humanistic socialism, the most important of which is a free, intelligent and loving person as the ultimate goal.

Especially close contacts E. Fromm supported with Yugoslav philosophers and sociologists of the «Praxis» group in Belgrade and Zagreb. Social support for the theoretical discussion around the «Yugoslav model» was obtained by the socio-psychological analytical approach of Erich Fromm and his concept of «social character». Fromm's concrete work finds expression in his attempt in 1957, with the help of Martin Buber, Naum Goldman, Ernst Simon and Din Pike, leaders of the Protestant Church in New York, to set up a committee that aims to return the Arabs to their former possessions. He later became a member of the Committee on New Alternatives in the Middle East and the National Committee of the American Association for Civil Liberties, and also widely collaborated in the Washington Institute for Peace Research. In 1968, Fromm took an active part in the campaign to nominate a humanist-minded senator - Eugene McCarthy, who opposed the Vietnam War. Although the outcomes of Fromm during the election campaign could not prevent Nixon from joining the Vietnam War, nonetheless, it was «an unprecedented Crusade in America» [6, pp. 131-132], which proved that a significant portion of the American population is ready for a humanization and is waiting for it. The book «The Revolution of Hope» emerged as a battle sheet in the election campaign for Y. McCarthy's presidency. Erich Fromm is convinced that a person can see himself in the true light if he can critically evaluate what is happening in the world. «It's impossible to see reality at one point if the rest of the world is closed from you», says E. Fromm [5, p. 65].

A political person always shows not only interest but the passion in all matters. Fromm opposes the ministry of intellectuals to any political party. Their task is to seek the truth in any way, to find the truth, and to speak the truth only. «Political progress depends on how much truth we know, how clearly and boldly we can express it and what part of it will inspire people» [5, p. 66]. He was not among the people who fear freedom and prefer to keep the illusion. Feeling extraordinary interest in politics, he tried not to depend on illusions in any sphere of life, believing that «a lie makes a man dependent, makes him hold on to any party, and only the truth ultimately leads to complete liberation» $[5, \mathrm{p} .68]$. The depth of the approach of E. Fromm is manifested, first of all, in the fact that he reveals the ethical and humanistic aspects of society, examines the global problems of the present in a broad socio-humanistic context.

The particular respect is the principledness of his vital position - «humanistic radicalism». Doubts, the power of truth, humanism - the guiding principles in the activity of both an individual and society as a whole. These principles are, according to Fromm, a triune formula and a reflection of the fundamental ideas embodied in Marx's short words: «Give in all doubts», «Truth will lead to release», «Nothing human is alien to me» [4, pp. 291-292].

From all the radical humanists from the times of Marx, Erich Fromm distinguishes the following: Toro, Emerson, Albert Schweitzer, Ernst Bloch, Ivan Ilyich; Yugoslav philosophers from the Praxis group - M. Markovich, G. Petrovich, S. Stoyanovich, S. Supek, P. Vranitsky; economist E.F. Schumacher; politician Erhard Eppler and many other representatives of religious and radicalhumanist unions in Europe and America of the 20th century. Their views coincide in the following:

1) The relationship between man and nature must be based not on exploitation, but co-operation;

2) The production must serve a person, not an economy;

3) Antagonisms must be replaced everywhere with the solidarity relation;

4) The highest goal of all social measures should be human good and the prevention of human suffering;

5) The health and welfare of man serves not the maximum consumption, but only reasonable;

6) Every person should be interested in active activities for the benefit of other people and involved in it. 
The concept of Fromm's humanism is based on the idea of human nature, inherent in all human beings. His views on «humanistic radicalism» E. Fromm prescribes in the «Foreword» in the book of Ivan Ilyich «Triumph of the Mind» [2, pp.4-8].

«Radicalism» for E. Fromm is, above all, an approach that can be characterized by the motto «de omnibus dubitandum», that is, everything must be questioned, especially those ideological concepts that virtually all are accepted by faith and, as a result, take upon themselves the role of indisputable, consistent with common sense, axioms. Under the «doubt» in this case, one does not need to bear in mind the psychological state of a person, which does not allow her to come to decisions or beliefs (for example, the doubt is based on an obsessive idea). According to Fromm, «to doubt» means being able to critically examine all the assumptions and established laws that have become a subject of blind worship under the guise of common sense, logic and what is considered natural and understandable.

Radical doubt is possible if a person expands the possibilities of his consciousness, penetrates the unconscious side of the course of their thoughts. «Radical doubt» is the discovery and disclosure, a gradual realization that his great goals for existence are no more than the fruit of human imagination. Radical doubt, according to Fromm, does not necessarily mean a denial, although it implies a rejection of faith. It is easy to deny, simply asserting the inverse of an existing one. For us, it is deeply important that radical doubt is dialectical: it covers the process of struggle against opposites and aspires to a new synthesis - to deny and assert. The radical doubt is the process of liberation from idolatrous thinking, the process of expanding consciousness, the process of the figurative, creative vision of a person of his possibilities, of his choice.

Erich Fromm focuses on global thinking, which is based on the implementation of the principle of humanistic radicalism, which opens up multiple prospects for the development of the wealth of human nature. Fromm himself had such thinking. Thanks to his efforts (along with the efforts of his supporters and followers), the scientific-theoretical and socio-psychological turn to the anthropological dominant was carried out [1, p. 74].

\section{Conclusions.}

1. A valuable priority of humanitarian branches of knowledge with the breadth of anthropological issues is the fact of today. The case started by Erich Fromm not only has not lost its significance but also because of the scale and humanist orientation, requires its continuation both in human research activities and in its everyday socio-cultural life in general, while maintaining a dialogic relationship with the world.

2. The breadth of views, dialogic thinking and high tolerance of E. Fromm is a valuable basis for the unification of scientists from the twentieth and twenty centuries to further develop and implement his project of «humanistic radicalism». Philosophical studies of the philosopher, is the bearing theoretical construct for many philosophical studies both in our country and abroad, can be used as the basis for the practical implementation of the projects of creation of man by various social institutions.

\section{REFERENCES}

1. Brown Roger, Social Psychology, New York: Free Press, 1995.

2. Malakhov V.S., Once again about the end of history // Questions of Philosophy, Moscow, 1994, № 7-8 [Малахов В.С., Еще раз о конце истории// Вопросы философии, Москва, 1994, № 7-8 (Malakhov V.S., Yeshche raz o kontse istorii// Voprosy filosofii, Moskva, 1994, № 7-8)].

3. Marx K., Confession// K. Marx, F. Engels, Op. T. 31, Moscow, 1978 [Маркс К., Исповедь // К. Маркс, Ф. Энгельс, соч. Т. 31, Москва, 1978 (Marks K., Ispoved'// K.Marks, F.Engel's, Soch. T. 31, Moskva, 1978)].

4. Fromm E., About love of life// E. Fromm. Psychoanalysis and ethics, Moscow, 1998 [Фромм Э., О любви к жизни// Э. Фромм. Психоанализ и этика, Москва, 1998 (Fromm E., O lyubvi k zhizni// E. Fromm. Psikhoanaliz i etika, Moskva, 1998)].

5. Fromm E., Introduction to Illch`s Celebration of Awareness// Ivan Illich: Celebration of Awareness, London: Calder \& Boyas, 1967.

6. Funk R., Erich Fromm. Pages of documentary biography/ R. Funk, Moscow: Drofa, 2011 [Функ Р., Эрих Фромм. Страницы документальной биографии/ Р. Функ, Москва: Дрофа, 2011 (Funk R., Erikh Fromm. Stranitsy dokumental'noy biografii/ R. Funk, Moskva: Drofa, 2011)]. 